\title{
Representações da violência em A guerra dos bastardos, de Ana Paula Maia
}

Elena Losada Soler ${ }^{1}$

\section{Questões de gênero(s)}

As violências e suas formas de representação fazem parte do paradigma da ficção policial?² Não é obrigatório que assim seja. Embora a violência faça parte substancial de um gênero literário que tem o crime como tema, nem todos os romances policiais contêm representações da violência num nível parecido ao encontrado em A guerra dos bastardos. Subgêneros do policial, como a novela de enigma ou a novela de mistério, podem, por exemplo, não apresentar imagens fortemente violentas, que são, no entanto, habituais no noir ou no hard-boiled.

A guerra dos bastardos pode ser considerado um romance policial? Apenas num sentido muito amplo do gênero. Sendo, de fato, o mais próximo ao gênero policial dos romances até agora publicados pela autora, $^{3}$ trata-se, porém, de uma ficção fronteiriça, híbrida, onde o gênero policial dialoga com outras formas de ficção urbana que têm a presença de imagens violentas como parte inquestionável do paradigma. Estamos, como afirma Cláudia Castanheira em relação a Patrícia Melo, perante "uma versão mais moderna do roman noir, um tipo de romance policial em que os modelos mais rígidos desse gênero são substituídos por uma abordagem mais ampla e flexível, sobressaindo a violência bruta"' (Castanheira, 2010, p. 241).

${ }^{1}$ Doutora em literatura portuguesa e professora da Universitat de Barcelona (UB), Barcelona, Espanha. E-mail: losada@ub.edu

2 Este trabalho faz parte dos resultados do projeto de pesquisa Víctimas y Agresoras. Representaciones de la Violencia en la Narrativa Criminal Escrita por Mujeres (Vanacem), desenvolvido no âmbito do grupo de pesquisa Creación y Pensamiento de las Mujeres (UB).

${ }^{3}$ A trama do romance, situado num Rio de Janeiro nunca nomeado, é a seguinte: Amadeu - um ator pornô de segunda linha - está, por uma vez, no lugar certo no momento certo. Vê o assassinato de um sicário, o infarto do assassino, e foge levando com ele uma bolsa vermelha cheia de cocaína que pertence a um grande empresário do cinema pornô e do tráfico de droga. Todo o argumento é construído em torno da "guerra dos bastardos" - sicários, aventureiros, nacos de ser humano, buscadores uma vida melhor -, que se desencadeia pela possessão da bolsa. Uma guerra cheia de sangue e outros fluidos, com corpos aos pedaços, corridas, atropelamentos, personagens a entrar e sair levados por acasos impossíveis, assassinatos, confusões de apartamento, humor negro, muita crueldade e uma sombria visão do mundo. 
Ainda assim, A guerra dos bastardos pode ser considerado um roman noir? Pode o policial aceitar a dilatação infinita dos seus limites? Possivelmente não, esse gênero nasceu como literatura popular e por isso precisa de um paradigma básico que deve ser mantido, porque aquilo é o que o leitor espera encontrar e reconhecer, embora também isso esteja mudando. No sentido mais restrito desse paradigma, que marca um processo de investigação e um final fechado, A guerra dos bastardos não é estritamente um policial, nem um policial noir, aproxima-se mais das etiquetas de "romance urbano" ou "romance da marginalidade". Minha proposta é usar neste caso o conceito "romance criminal", porque amplia o campo. A guerra dos bastardos pode não ser um policial, não ser um noir, mas é, sem dúvida, um criminal.

O romance criminal, com ou sem pesquisa, com ou sem - geralmente sem - restituição da ordem social atacada pelo crime, gera sempre uma reflexão sobre a realidade social. É sempre, de uma maneira ou de outra, uma reflexão sobre: a inocência - a da vítima, inocente ou talvez não -;a culpabilidade - a do criminoso, culpado ou talvez não -; o entorno coletivo dessa inocência e dessa culpabilidade; e as obscuras formas do mal na condição humana. Raramente, porém, o mal no romance policial/urbano/marginal/criminal é absoluto, grandioso ao modo dantesco ou dostoyevskiano; 4 costuma ser um mal quotidiano, comum, que tem as suas raízes na cobiça e no sexo, um mal banal. E o adjetivo leva-nos imediatamente à Hannah Arendt de Eichman em Jerusalém: "Apesar dos esforços do procurador da Justiça, qualquer um podia ver que aquele homem não era um 'monstro', verdadeiramente tornava-se difícil não suspeitar que era apenas um palhaço" (Arendt, 2004, p. 85, tradução nossa). Em A guerra dos bastardos, Ana Paula Maia, como Cláudia Castanheira aponta sobre Patrícia Melo, atrai o leitor precisamente com "a banalização do crime, a desvalorização total da vida humana e o descaso e a omissão das autoridades com o que se costuma chamar 'estado paralelo no Brasil'" (Castanheira, 2010, p. 243).

A violência - ou melhor a representação da violência, sua transformação em matéria literária, ou seja, em experiência estética - é parte essencial e constituinte de todos os gêneros de ficção urbana antes referidos. Uma violência que costuma estar presente como violência visual já nos

\footnotetext{
${ }^{4}$ A referência direta a Crime e castigo em A guerra dos bastardos é uma óbvia hipérbole e ressalta ainda mais a mediocridade das personagens.
} 
paratextos gráficos, as capas, as contracapas e os booktrailers, ${ }^{5}$ que são o primeiro contato do leitor com o texto. Se analisarmos as capas da edição brasileira e da edição portuguesa de A guerra dos bastardos - para além do booktrailer, onde o sangue é a nota dominante -, nota-se imediatamente que a capa brasileira enfatiza muito mais a violência: as cores preta e vermelha sugerem-na como primeira impressão, seguida e reforçada pela contundência da imagem: uma mão masculina fechada empunhando um soco-inglês. Na capa portuguesa, pelo contrário, as cores são mais frias, com tons cinzentos e acobreados, num desenho quase abstrato de cabos e pedras quebradas a sugerirem mais ruína do que violência.

Apesar, porém, da representação da violência fazer parte essencial dos gêneros de ficção urbana, essas imagens ainda resultam chocantes e suscitam debate - mesmo tendo em conta os já notórios precedentes na literatura brasileira - quando aparecem num romance escrito por uma mulher. A cultura patriarcal identifica e justifica o uso e a representação da violência como parte da construção normativa da masculinidade, ainda nos casos em que é considerada uma mostra de desvio das condutas socialmente aceitáveis. A violência exercida ou representada literariamente pelas mulheres, no entanto, é uma dupla transgressão: contra a estrutura cultural patriarcal, que denega à mulher a capacidade de atuar com violência, exceção feita ao que seria o seu "mandato biológico" de proteção dos filhos, e contra algumas teorias feministas que almejam uma espécie de "anjismo feminino". Esse foi - como apontou Adriana Cavarero, que o definiu como "catástrofe simbólica" (Cavarero, 2009, p. 180) - o poder devastador das imagens das torturadoras de Abu Ghraib, mulheres "usurpando" a maldade masculina, aquela que a filósofa Amelia Valcárcel chamou "o mal do amo" (Valcárcel, 1994, p. 165).

Escritoras como Ana Paula Maia ou Patrícia Melo resultam incômodas para alguns feminismos clássicos, em especial para o feminismo da diferença, porque interpretam os problemas de gênero de outra maneira. Longe de assumir uma escrita que torne visível a mulher autora e a mulher personagem, Patrícia Melo ou Ana Paula Maia escrevem textos fora de dois estereótipos: o da "literatura feminista", que imagina representações femininas vindicativas, com os traços do que as mulheres "deveriam ser", ou seja, conscientes e com agência; e o patriarcal, que

\footnotetext{
${ }^{5}$ Disponível em: 〈www.youtube.com/watch?v=tCzd4mIuWoY>.
} 
identifica a produção literária das mulheres com o intimismo e com uma boa dose de pieguice. Contra esses lugares comuns, Patrícia Melo e Ana Paula Maia trabalham com narradores e com personagens protagonistas masculinas, muitos deles assassinos, muitos deles marginais, sempre violentos. De fato, não se trata de um abandono da análise de gênero senão de uma fase diferente dessa análise centrada na masculinidade, exemplificando as relações de gênero através da figura masculina, como ressalta Lúcia Osana Zolin: "livros narrados em primeira pessoa, por narradores masculinos, não raramente identificados como assassinos, narrando questões relacionadas ao universo do crime em que se encontram imersos" (Zolin, 2007, p. 107).

Em uma entrevista no Jornal Rascunho, Ana Paula Maia afirma: "Tenho muita dificuldade de escrever sobre mulheres, sobre o universo feminino. Todas as vezes que tento escrever com uma voz feminina fica horroroso [...]. Tenho uma identificação com o universo masculino" (Maia, 2011, p. 11). Esse é um discurso que começa a ser frequente e que deveria levar-nos a refletir sobre a recusa de muitas jovens escritoras à identificação tradicional e dicotômica masculino-feminino - que também não é alheia aos pós-feminismos - e noutros casos, mais perturbadores, à representação literária quase fascinada pela violência e por masculinidades heteronormativas e patriarcais.

\section{Ferramentas metodológicas para a análise da representação da(s) violência(s)}

Como e com quais ferramentas críticas podemos analisar a representação da(s) violência(s) nesses textos ficcionais? Obviamente, precisamos de metodologias interdisciplinares. A análise da violência real implica elementos sociais, culturais, políticos e precisa, para seu estudo, da interação de discursos e conceitos de disciplinas muito diversas: filosofia, psicologia, sociologia, criminologia/vitimologia, teoria das emoções, estudos de gênero e análise do discurso; sem esquecer, porém, que quando nos aproximamos do texto em sua literariedade, precisamos também das ferramentas clássicas da análise literária. Cada um desses discursos críticos tem como objetivo a análise 
prioritária de uma das formas de violência. Referiremos apenas aqueles que mais utilidade têm mostrado para o nosso trabalho. ${ }^{6}$

A filosofia tende à análise da violência política, embora às vezes seja possível estabelecer ligações com o tipo de violência própria do romance criminal ou urbano, porque reflexões como a de Hannah Arendt em Sobre a violência ${ }^{7}$ podem ser também úteis para nos ajudar a pensar que o que acontece com as personagens "raivosas" de Fonseca, Melo e Maia é exatamente o contrário: nem chegam a imaginar que as condições poderiam se modificar coletivamente, porque, como afirma Pere Comellas, trata-se: "de uma guerra de classes, mas sem projeto nem saída" (Comellas, 2014, p. 56). Também os trabalhos de Slavoj Žižek aportam conceitos aplicáveis a esses estudos, especialmente a dicotomia violência subjetiva versus violência objetiva: "A violência objetiva é invisível porque suporta a normalidade de nível zero contra o que percebemos como subjetivamente violento" (Žižek, 2013, p. 10, tradução nossa). E também uma ideia perturbadora: "a dimensão propriamente inumana do próximo" (Žižek, 2013, p. 73, tradução nossa). Um dos primórdios de qualquer ação violenta, como bem sabemos, é a desumanização do Outro, contra quem toda violência é permitida por simplesmente não ser Eu. O que nos leva a uma ideia importante formulada por Adriana Cavarero (2009, p. 45): a ontologia individualista da desvinculação. Em oposição a Hobbes, Cavarero aponta que a filosofia, em sua obsessão pelo Homem em abstratas maiúsculas, criou a ilusão de um eu autosuficiente: "[Hobbes] é o principal autor de uma ontologia da desvinculação, cujos protagonistas são descritos como sujeitos atomizados, autorreferenciais, fechados sobre si próprios e concentrados no desejo de manter sua vida em detrimento da do outro" (Cavarero, 2009, p. 47-48, tradução nossa).

Essa desvinculação é óbvia nas personagens de A guerra dos bastardos, que são um verdadeiro somatório de solidões. Apesar da sua condição de deslocados do sistema e de serem suas vítimas, essas personagens trasladam às suas condutas um dos traços essenciais da modernidade $\mathrm{e}$ do capitalismo: o individualismo e a dissolução dos vínculos sociais, o

\footnotetext{
${ }^{6}$ Nosso atual projeto de pesquisa - Víctimas y Agresoras. Representaciones de la Violencia en la Narrativa Criminal Escrita por Mujeres (Vanacem) - analisa as formas de violência contra as mulheres e também das mulheres representadas no romance criminal.

7 "A raiva brota apenas onde existem motivos para imaginar que essas condições poderiam ser modificadas e, no entanto, não se modificam” (Arendt, 2013, p. 83, tradução nossa).
} 
que os torna ao mesmo tempo agressores e vulneráveis. Seguindo a conceitualização de Adriana Cavarero - "inerme é substancialmente quem se encontra numa condição de passividade e sofre uma violência da qual não pode fugir nem responder" (Cavarero, 2009, p. 59, tradução nossa) -, nenhuma dessas personagens é objetivamente "inerme", ainda assim, nas circunstâncias peculiares em que se encontram, tornam-se "inermes" e, sem dúvida, todas elas são vulneráveis, no sentido de serem corpos abertos ao Outro. Uma das mostras maiores dessa vulnerabilidade é a recorrência quase paródica no romance de imagens de corpos desmembrados, um desmembramento que "cancela a unicidade [do corpo] reduzindo-o à carne sem nenhuma unidade de figura" (Cavarero, 2009 , p. 53, tradução nossa). São corpos torturados, violados em sua dignidade ontológica (Cavarero, 2009, p. 182). Uma dignidade que Amadeu, moribundo, sente ferida não tanto pela proximidade da morte quanto pela mutilação da orelha, em mais uma das referências cinematográficas presentes no romance, como aponta Christiane Quandt: "uma orelha solta e perdida no acidente - talvez uma referência a Blue Velvet de David Lynch?" (Quandt, 2015, p. 304). Essa orelha no meio da rua, exposta a todos os olhares e que viverá uma vida própria, separada do corpo até acabar num saquinho de plástico, faz-nos lembrar que, contrariamente ao que costumamos pensar, o corpo nunca é "privado", sempre é público, constantemente exposto ao "Outro" para ser acarinhado, ignorado ou ferido, como aponta Judith Butler:

O corpo é mortalidade, vulnerabilidade, práxis: a pele e a carne expõe-nos ao olhar dos outros, e também ao contato e a violência, e também são os corpos os que nos põem em perigo de tornarmo-nos agentes e instrumento de tudo isto [...]. O corpo tem uma dimensão invariavelmente pública (Butler, 2006, p. 52, tradução nossa).

A sociologia, especialmente na voz de Pierre Bourdieu, e a teoria de resolução de conflitos do sociólogo e matemático Johan Galtung fornecem-nos também ferramentas de grande utilidade. A complexa teorização de Bourdieu sobre as formas e mecanismos de reprodução da violência simbólica - definida como "todo poder que chega a impor significados e a impô-los como legítimos disfarçando as relações de força que estão na base deles" (Bourdieu, 1972, p. 18, tradução nossa) - permite estudar as profundas raízes de condutas aparentemente individuais, ilógicas ou fruto de doenças de foro psiquiátrico. Essas análises complementam-se perfeitamente com os quadros geométricos sobre 
conflito e violência de Johan Galtung, que tem uma insólita e sugestiva definição da violência: "Entendo a violência como afrontas evitáveis às necessidades humanas básicas" (Galtung, 2003, p. 262, tradução nossa). Seu famoso "triângulo da violência" facilita-nos muito a análise diferenciada entre "a violência que opera sobre o corpo e a violência que opera sobre a alma" (Galtung, 1995, p. 317, tradução nossa). O triângulo de Galtung é um equilátero partido pela metade - com a "violência visível" no vértice superior, a parte mais pequena, e a "violência invisível" na base, muito maior - que tem como vértices a "violência direta" no superior, a "violência cultural" no inferior esquerdo, e a "violência estrutural" no inferior direito (Galtung, 1998, p. 15). Galtung define assim as três categorias:

No que diz respeito ao discurso sobre a violência, ficaremos com a distinção entre violência direta, deliberadamente dirigida a insultar as necessidades básicas de outros, violência estrutural, que incorpora a esses insultos as estruturas sociais e mundiais em forma de exploração e repressão, e violência cultural, que refere aos aspectos da cultura (como religião e linguagem) que legitimam a violência direta e estrutural (Galtung, 2003, p. 69, tradução nossa).

Esse triângulo é a imagem mais simples e ao mesmo tempo a mais esclarecedora da complexidade do fenômeno da violência. É flexível e inclusiva - o patriarcado seria, nessa figura, claramente uma forma combinada de violência cultural e estrutural, por exemplo - e permite, aliás, se o triângulo for colocado sobre um ou outro desses vértices, focalizar aspectos diversos:

Quando colocamos o triângulo sobre as suas bases de violência direta e estrutural, a imagem que suscita é a da violência cultural como legitimadora de ambas. Se o triângulo for colocado sobre o ângulo da violência direta, projeta a imagem das origens estruturais e culturais da violência direta. Obviamente o triângulo é sempre um triângulo, a imagem produzida, porém, é diferente, e as seis posições possíveis [...] evocam histórias diferenciadas, que merecem ser contadas (Galtung 2003, p. 265, tradução nossa).

Para a análise específica das formas de violência urbana moderna recorrentemente descritas na ficção latino-americana, são também interessantes as reflexões do sociólogo Roberto Briceño León, que define essas manifestações como: "uma violência não política, porque não tem vocação de poder" (León, 2002, p. 35). Briceño segue as teorias do strain 
social formuladas nos anos 1950 pela criminologia funcionalista de Robert King Merton: "Dado que as metas culturais são desejadas por todos e que as oportunidades estruturais para consegui-las são limitadas, surge uma tensão (strain), uma situação de anomia" (apud Larrauri, 2000, p. 5). Na sequência dessa ideia, Briceño aponta: "A presença permanente dos mídia e, sobretudo, da televisão, coloca os indivíduos de diferentes níveis sociais e de diferente capacidade aquisitiva em contato com um conjunto de bens, serviços e estilos de vida que muitos deles não podiam conhecer ou imaginar" (Briceño, 2002, p. 40). A origem da violência delinquencial não seria assim, ou não apenas, a pobreza senão a contemplação de um horizonte de expetativas de consumo que não se poderiam realizar dentro da ordem estabelecida. Embora isso seja certo em determinados tipos de violência e resulte útil para explicar muitas das formas de violência representadas em A guerra dos bastardos - a de Amadeu, por exemplo -, essa consideração é incompleta, como ressaltaram correntes criminológicas posteriores, posto que não explica a razão pela qual, com a mesma impossibilidade de acesso aos bens que a mídia mostra, um indivíduo delinque e outro não, nem esclarece a origem da violência daqueles que têm acesso à riqueza.

\section{Taxinomia das violências em A guerra dos bastardos}

O romance de Ana Paula Maia oferece-nos um completo repertório de formas de violência, que é de fato um dos eixos estruturantes do texto. Para o estabelecimento de uma taxinomia dessas violências, seguiremos o modelo proposto no triângulo de Galtung. A primeira classificação é vertical: violências visíveis e violências invisíveis. A segunda diz respeito aos vértices do triângulo: violências diretas, violências estruturais e violências culturais - embora, em muitos casos, apareçam entrelaçadas.

\section{1) Violências visíveis}

a) Violência direta, física, agressão corporal, violência verbal

As várias formas de violência física e de violência verbal direta são as mais habituais e óbvias da violência visível, as que fazem reagir o leitor de maneira imediata. No romance de Ana Paula Maia a violência direta encontra-se sob a forma constante de golpes, socos, pontapés e demais formas de agressão física entre corpos, mas também nos disparos, facadas e 
demais violências feitas com os mais diversos objetos materiais. Tem, aliás, uma manifestação recorrente e extrema: o já referido desmembramento dos corpos. A primeira ocorrência é a descrição do atropelamento de Amadeu pelo carro de Edgar Wilson e Pablo Sasaki, numa sequência de acasos inverossímeis que obriga o leitor a reestruturar o seu pacto de leitura. No começo da cena, o leitor não é consciente de que a vítima seja Amadeu, porque é situado perante formas de representação não literárias. Se, no caso da obra de Rubem Fonseca, os recursos tomados de outras artes ou da literatura popular aparecem misturados com reflexões metaliterárias e alusões a textos fundamentais do cânone ocidental, como expõe Pere Comellas (2014, p. 53), na obra de Patrícia Melo ou de Ana Paula Maia, as referências à chamada "alta literatura" diminuíram ou desapareceram em benefício da intertextualidade com outras formas culturais, fundamentalmente visuais.

Ana Paula Maia descreve o atropelamento de Amadeu através de um uso do presente que é próprio dos roteiros e as descrições cinematográficas, mas que é alheio à tradição das descrições factuais na literatura. Trata-se de uma forma de interferência entre artes, constante no texto e que, como aponta Chriatiane Quandt, produz uma contaminação intermídia:

Se olhamos para a morte de Amadeu em sua totalidade, poderíamos também categorizá-la como contaminação parcialmente atualizadora (Teilaktualisierende Systemkontamination). Um indicador dessa forma de contaminação intermidial é a utilização do presente como tempo narrativo, que é o caso na passagem em questão, e a apropriação das regras do sistema de referência, ou seja as sequências de imagens descritas, quase cinematográficas, na hora da morte do ator pornô Amadeu [...]. Assim se dá uma aparente simultaneidade entre o tempo narrativo e o tempo narrado que, em conjunto com as imagens impactantes e coloridas, desconstrói o discurso narrativo literário criando a ilusão de um discurso fílmico que se vela de ferramentas fílmicas. (Quandt, 2015, p. 305-306)

Nesse trecho, as personagens são apenas marionetes que entram e saem representando uma lentíssima agonia que desfaz o que de humano poderia haver em Amadeu. A preocupação maior do moribundo, porém, não é, como já foi apontado, a probabilidade da morte, mas o pedaço do seu eu que lhe falta: a orelha. $\mathrm{O}$ resto do corpo a morrer não lhe interessa, a parte tornou-se o todo: 
O motorista sai e, abaixado, retira um lenço quadriculado do bolso e desgruda a orelha do farol, tapando a boca para não vomitar. Ele retorna muito agitado para o carro, estende a mão para trás, passa o lenço com a orelha e arranca com o carro antes que um guarda municipal o alcance. "Tome a tua orelha e agora cale essa boca" (Maia, 2007, p. 93).

Também o sicário Pablo Sasaki trafica com órgãos humanos, e o eufemismo usado pela autora - "comercializar alguns órgãos ainda intactos de corpos que chegavam ao anatômico para fins diversos" (Maia, 2007, p. 105) - tinge o texto de um tom cômico ao propor uma normalização da anormalidade.

A obsessão por cortar, por despedaçar, é um traço distintivo de Edgar, personagem que transita por vários romances da autora: "Edgar, que mania de tornar tudo menor. Eu acho que [...] ele sempre teve esse costume de diminuir as pessoas, inferiorizá-las" (Maia, 2007, p. 261). É exatamente isso, a fragmentação do corpo torna os nacos não humanos, carne apenas. Se aplicarmos os conceitos de Adriana Cavarero, a desvinculação entre o mutilador e o mutilado é ao mesmo tempo real, cheia de humor cruel, que é uma forma frequente de representação literária da violência física, e também simbólica e psicológica. Observase muito claramente na imagem do dedo cortado do músico:

Segura ainda mais firme o homem ao perceber o aço que se precipita rápido sobre seu dedão. [...] Ele não quer olhar, sua ferramenta de trabalho, o sustentáculo para a execução da flauta, seu polegar opositor não existe mais e isso o torna menos humano, menos racional. (Edgar destampa a janela de feijão e joga o dedo lá dentro, junto de pés, orelhas e costelas de porco. (Maia, 2007, p. 205-206).

É o apogeu da desumanização, a carne humana animalizada, tornada comida para canibais involuntários como os que consumiram os bifes de dona Betinha: "Amolou o cutelo com esmero e, durante as Salve-rainhas, desossou dona Betinha. [...] A mulher resultou em robustos e gordurosos bifes sangrentos, pois seus largos quadris produziram alimento para muitos dias de festa" (Maia, 2007, p. 103).

b) O abjeto, o inominável, o tabu: fluídos, excreções e secreções (homenagem ao mestre Fonseca)

A violência pode residir também na linguagem, naquilo que se verbaliza, no uso da palavra que não se deve dizer e na elipse. $\mathrm{O}$ 
recurso ao tabu, a nomear obscenamente aquilo que socialmente não deve ser nomeado, verbalizar o abjeto, é uma forma de violência. Em A guerra dos bastardos o abjeto toma a forma, como em Rubem Fonseca, de referência constante aos fluídos inomináveis do corpo: "e ali cada um carregando seus próprios excrementos em potinhos de plástico" (Maia, 2007, p. 23).

Um desses fluidos - o sangue, o fluido essencial, fluido de vida e de morte - domina o texto por sua recorrência. O sangue impregna a bolsa de cocaína como premonição do que há de acontecer a quem se aproximar dela; suja o carro onde Amadeu está morrendo, para horror do proprietário; e o mesmo sangue de Amadeu invade contamina - o corpo alheio de Horácio: "Não para de gritar e cospe sangue num ato involuntário. Horácio limpa o sangue do seu rosto e fala desesperado" (Maia, 2007, p. 92).

c) Violência homem/animal

Essa forma de violência, recorrente em toda a obra de Ana Paula Maia, aparece em A guerra dos bastardos nalguns casos como violência em legítima defesa, homem e animal igualados no horror, o humano animalizado e o animal contaminado pela maldade do homem. Nesses casos, as descrições, absolutamente gore, são particularmente atrozes, como no caso da "guerra" de Lozzoni, supostamente o "homem", contra a ratazana Rasputin, supostamente o "animal". Trocando os seus papéis, Lozzoni acaba por matá-la às dentadas, e esse sujo combate aparece mais uma vez cheio de "fezes, sangue e saliva", os fluidos abjetos:

Ao acordar, uma cavidade rasgada em seu antebraço, os dentinhos cravados na carne até os ossos, lambuzada de sangue morno, os olhinhos brilhando no princípio das trevas, fezes sangue e saliva dentro da ferida exposta com as veias arrebentadas e corroídas fluindo através da garganta de Rasputin [...]. Até que um dia Rasputin entrou em casa [...]. Quando a alcançou, o ódio de Lozonni era tamanho que a despedaçou com os dentes (Maia, 2007, p. 36).

Homens maus, animais maus, como os tubarões alimentados com ouriços venenosos para eles não atacarem os pescadores (Maia, 2007, p. 52), uma imagem que gera uma perturbadora e dostotevskiana reflexão de Horácio: "Amadeu, só os tubarões merecem ouriços venenosos?" (Maia, 2007, p. 53). Os homens que aparecem em A guerra dos bastardos 
não são bons, os animais também não, são animais desagradáveis, invasores do espaço humano, inimigos: "Penso que esses malditos pombos comeriam a minha cara, ou melhor, eles me comeriam até os ossos e depois me cagariam por toda a cidade" (Maia, 2007, p. 145). E como inimigos serão tratados: "Me divirto como posso, matando os pombos do telhado" (Maia, 2007, p. 143).

Às vezes, porém, a relação violenta entre homens e animais assume aspectos de comicidade. É o caso de Pablo Sasaki e do chihuahua que comeu o piercing dele. Durante todo o romance receamos ser confrontados com terríveis torturas para o cãozinho, mas Pablo acaba tendo com ele os mimos que não tem com os humanos e esperando pacificamente a devolução, pelo meio biológico óbvio, do objeto "roubado".

A contradição entre o desprezo pela vida humana e o amor aos animais torna-se também cômica pela hiperbolização das situações no caso de Gerson, o sicário que ama os animais e não suporta a caça (Maia, 2007, p. 23). O homem que é capaz de dar 32 facadas num corpo humano é capaz também de "libertar" uma cabeça de veado do seu destino de troféu para enterrá-la na floresta (Maia, 2007, p. 235).

d) O grotesco como violência verbal

O uso do grotesco como forma de comicidade, quando aplicado a um contexto tão violento como o desse romance, gera um efeito semelhante ao impacto da violência verbal, por seu turno, onipresente sob a forma de gritos, palavrões e insultos trocados entre as personagens. A cena em que a diretora de cinema Edwiges, que está filmando numa igreja, tem tratos com os traficantes no confessionário e esconde o dinheiro e a droga na prótese da perna manca apresenta-a como uma cyborg grotesca: "Ela retorna à postura anterior trazendo nas mãos um objeto não esperado, causando o afastamento dos dois, colando-se ao fundo do cubículo e expressando horror ao ver a perna da mulher agora suspensa em suas mãos. Há o desejo de cair na gargalhada, de sair correndo" (Maia, 2007, p. 78).

e) Autoviolências

A violência cometida por um sujeito contra si próprio é também - e às vezes é preciso recalcá-lo apesar da obviedade - violência. Pode manifestar-se em pequenas autolesões, habitualmente cortes, ou em mutilações mais graves. É o suicídio uma forma de autoviolência? A 
questão é polêmica. Se o aceitarmos como tal encontramos um exemplo em A guerra dos bastardos: a triste morte de D. Gisela, mais uma vez envolta em sangue, fluido essencial, o símbolo de vida tornado representação da morte, uma morte fruto da solidão, do extremo isolamento urbano: "Os olhos tristonhos arregalados e a rachadura na testa vazavam sangue. A velha Gisela se atirou do prédio onde morávamos" (Maia, 2007, p. 141).

\section{2) Violências invisíveis}

As formas básicas da violência invisível são a estrutural e a cultural, que muitas vezes acabam por derivar em violência direta. Também elas aparecem profusamente em A guerra dos bastardos.

a) Pornografia

A pornografia pode ser considerada uma forma de violência cultural. Às vezes ligada diretamente com a violência física: “Amadeu está em duas cenas com Greice Sally, e na primeira, ela recebe algumas bofetadas" (Maia, 2007p. 122). Noutros casos contribui mais sutilmente para a permanência de estereótipos patriarcais, como encontramos nas afirmações sobre a supremacia do "pau" no cinema pornô (Maia, 2007, p. 59). Por outro lado, reifica e fragmenta a mulher, como no caso de Grace Sally, que existe apenas da cintura para abaixo, caraterizada como "a incrível xoxota engolidora de fogo" (Maia, 2007, p. 68). Nesse contexto, a mulher desumaniza-se, animaliza-se, como na terrível imagem inicial do romance, a da mulher-vaca:

Deu dois tiros na mulher. Um bem aqui no meio da testa. Pow! O outro no coração. Acredite, o silicone explodiu. Litros e mais litros sendo despejados na banheira", diz Salvatore. "Ele olhava pr'aquilo tudo escorrendo e imaginava a fortuna que jorrava dos peitos da vaca." (Ele deixou escapar", responde. "Mas antes mandou que ele mamasse nos peitos da mulher morta. Que chupasse todo o silicone" (Maia, 2007, p. 24-25).

b) Desvinculação urbana

A solidão e a desvinculação no meio urbano são particularmente visíveis no romance. As personagens falam umas com as outras, cruzam-se nas ruas, moram no mesmo prédio, mas a comunicação é nula e a preocupação com o outro inexistente. Para Horácio, dona Elza, 
sua vizinha, representa alguma coisa semelhante a um vínculo de cuidado entre dois seres humanos. No entanto, a inversão dos valores humanos, a violência cultural e estrutural é tanta que, mesmo reconhecendo a necessidade desse vínculo, o envergonha, porque põe em causa sua independência, seu individualismo, e o ato humano do cuidado é sentido como "degradante": "Se ficasse muito doente, ela levaria sopas e faria chás para ele. Para Horácio, dona Elza soa como um tipo de socorro presente, uma mão amiga morando um andar acima. É importante saber que certas pessoas se preocupam com você. Degradante pensamento, porém eficaz" (Maia, 2007, p. 50).

\section{c) O olho do grande irmão}

Uma das manifestações mais sutis da violência estrutural é o controle da população através da mídia, particularmente da televisão. Tornada o olho do grande irmão moderno, a televisão perpetuamente ligada banaliza a violência até o ponto de apagar a diferença entre a violência ficcional e a real, reproduzindo modelos humanos, dogmas sociais e códigos estéticos diretamente emanados das estruturas de poder. Paradoxalmente, porém, como neste trecho, sua constante presença acaba por anular seu poder, por se transformar "num aquário de tipos humanos raros": "Mas deixam a TV ligada. Aquilo funciona como uma espécie de aquário sortido de tipos humanos raros, batendo suas nadadeiras em ondas de pixels, nas águas azuladas do plasma reluzente" (Maia, 2007, p. 57).

d) Violência econômica

A violência econômica é uma afronta evitável às necessidades humanas, segundo a definição já referida de Johan Galtung. Os problemas econômicos de Gina são representados sob a imagem de uma dor física, uma agressão ao corpo: "Gina deve muito dinheiro. Os juros se acumulam e reagem como pontadas no estômago" (Maia, 2007, p. 137). O corpo de Gina, aliás, é agredido de muitas outras maneiras. $\mathrm{O}$ desporto que ela pratica não é lúdico, é uma atividade cruel: o box mist homem-mulher em combates clandestinos, onde os corpos são triturados e invadidos em troca de um dinheiro escasso. A luta entre Gina e Hugo Valentino, quem significativamente "concentra a sua fama em agressões contra mulheres" (Maia, 2007, p. 138), tem mais de 
símbolo de agressão sexual - diante da qual Gina reage usando as coxas como arma - do que de desporto.

Esses corpos agredidos tornam-se mais uma vez imagens de uma humanidade fragmentada - "O nariz, uma cartilagem esparramada, as maçãs do rosto deformadas por pequenos inchaços rosados" (Maia, 2007, p. 153) - ante um público-voyeur ainda mais violento, que espera ver a "garota" Gina vencida pelo monstro Hugo e acaba por ver exatamente o contrário.

e) Homofobia e machismo

A homofobia e o machismo - duas caras da mesma moeda - são dois fenômenos paradigmáticos do patriarcado, que Galtung considera em sua totalidade uma forma óbvia de violência cultural (Galtung, 2003, p. 71). Se o velho Lozzoni manifesta em altos berros uma opinião que ninguém lhe pediu - "Não gosto de músicos. Não gosto de bichas" (Maia, 2007, p. 132) -, Gerson, o sicário, parece retrucar com uma frase em que a potência expressiva da linguagem grosseira reforça a violência da ideia para levar-nos mais uma vez ao tema da fragmentação: um homem e uma mulher definidos exclusivamente pelos seus órgãos sexuais, como se nenhuma outra parte dos seus corpos existisse: "Por isso os homens ganham um pau e elas uma buceta. Gostam de ser fodidas, entende?" (Maia, 2007, p. 223).

\section{f) Corrupção policial}

A corrupção policial é uma das manifestações mais chocantes da violência estrutural e um dos grandes fracassos do sistema. Quando os pastores se tornam lobos alguma coisa fica irremediavelmente estragada na ordem social. Em A guerra dos bastardos encontramos um caso - raro de policial honesto: o tenente Miranda, que além de tudo é literato e gosta de Crime e castigo. Assassinado por Edgar, também será desmembrado: para dificultar a identificação, os sicários cortarão e levarão com eles a cabeça e as mãos de Miranda, simbolicamente as partes mais "humanas" do corpo: a capacidade de pensar e a capacidade de fazer. A cabeça de Miranda, tornada objeto, "coisa", inservível sem o seu corpo, andará aos tombadilhos na mala do carro e acabará por delatar os culpados: "Alguma coisa caiu do porta-malas e saiu rolando pelo asfalto" (Maia, 2007, p. 281). 
Fazendo face ao "bom policial" encontraremos também os "maus policiais", e o final da história da bolsa de cocaína ensanguentada acabará por depender deles numa apoteose de tiros, sangue e envelopes de dinheiro, na qual a violência chega a um nível tão excessivo que a tragédia vira rapidamente vaudeville: "Em uma noite que prometia apenas investidas frustradas e estilhaços de fuzis, um envelope com $27.000,00$. O policial mais alto ficou intrigado com as manchas de sangue em sua camisa. 'Que se danem as manchas de sangue, isso são 27.000,00', arremata o outro" (Maia, 2007, p. 287).

\section{Conclusões}

Observamos, pois, em A guerra dos bastardos, uma completa taxinomia de violências. Nesse romance, toda violência humana encontra, por sua vez, um paralelo no mundo inanimado. Se os corpos são segmentados, expostos em sua interioridade, os espaços são rotos, apodrecidos: "Os pisos rangem, sonoros, e as irregularidades do teto formam bolhas no rebaixamento de gesso, como se todo o lugar estufasse, inchasse, talvez até explodir" (Maia, 2007, p. 143). Domina uma sensação geral de ruína, ruína dos edifícios, ruína da moral humana, ruína do sistema... Ruína também do humanismo? Há quase vinte anos, na intervenção que causou a célebre polêmica com Jürgen Habermas, Peter Sloterdijk apontava: “Quem amansará o ser humano, se falhar o humanismo como escola de domesticação do homem? Quem amansará o ser humano se até agora os seus esforços para se autodomesticar conduziram-no apenas à conquista de poder sobre todo o existente?" (Sloterdijk, 2000, p. 52). É essa a ruína que assoma entre as páginas de A guerra dos bastardos? As capas do livro nas edições brasileira e portuguesa, entre a violência e a ruína, apontam nessa direção. No romance de Ana Paula Maia, todos os valores do humanismo sumiram ou se encontram invertidos. Apenas um exemplo: se a fala é a imagem do humano, o que devemos pensar desse Edgar Wilson, que fala quando está enfurecido e cala - recusa-se à comunicação? - quando está tranquilo? "É terrível quando fala demais, pois indica que está enfurecido. Enquanto alguns se calam, ele fala. E quando se cala, é sinal de total tranquilidade" (Maia, 2007, p. 149).

E para rematar o fracasso do humanismo, lembremos a aprendizagem de Gina: só quem bate sobrevive: "Aprendeu desde 
pequena a bater. [...] 'Se te maltratarem, bata! Se te ofenderem, bata! Se xingarem a tua mãe, bata! Se tiver medo, bata! Se não estiver de acordo, bata!'” (Maia, 2007, p. 170). E nesse onipresente bater, na vida de Gina e no romance, encontra-se o núcleo da tragédia.

\section{Referências}

ARENDT, Hannah (2004). Eichmann en Jerusalén. Tradução de Carlos Ribalta. Barcelona: Debolsillo.

ARENDT, Hannah (2013). Sobre la violencia. Tradução de Guillermo Solana. Madrid: Alianza.

BOURDIEU Pierre (1972). Esquisse d'une théorie de la pratique. Paris: Droz.

BUTLER, Judith (2006). Vida precaria. Tradução de Fermín Rodríguez. Buenos Aires: Paidós.

CASTANHEIRA, Cláudia (2010). Marcas da violência e jogos do poder no romance urbano de Patrícia Melo. Estudos de Literatura Brasileira Contemporânea, Brasília, n. 36, p. 241-250.

CAVARERO, Adriana (2009). Horrorismo. Nombrando la violencia contemporània. Tradução de Saleta de Salvador Agra. Barcelona: Anthropos; México: Universidad Autónoma Metropolitana.

COMELLAS, Pere (2014). Rubem Fonseca e o policial noir. Abriu: estudos de textualidade do Brasil, Galicia e Portugal, Barcelona, n. 3, p. 51-69.

GALTUNG, Johan (1995). Investigaciones teóricas. Sociedad y cultura contemporáneas. Madrid: Tecnos.

GALTUNG, Johan (1998). Tras la violencia, 3R: reconstrucción, reconciliación, resolución. Bilbao: Bakeaz; Gernika Gogoratuz.

GALTUNG, Johan (2003). Paz por medios pacíficos. Paz y conflicto, desarrollo y civilización. Bilbao: Bakeaz; Gernika Gogoratuz.

LARRAURI, Elena (2000). La herencia de la criminología crítica. Madrid: Siglo XXI.

LEÓN, Roberto Briceño (2002). La nueva violencia urbana de América Latina. Sociologias, Porto Alegre, ano 4, n. 8, p. 34-51.

MAIA, Ana Paula (2007). A guerra dos bastardos. Rio de Janeiro: Língua Geral. 
MAIA, Ana Paula (2011). Entrevista ao Paiol Literário. Jornal Rascunho, Curitiba, n. 136, ago. Disponível em: http://rascunho.com.br/ana-paula-maia/. Acesso em: 9 set. 2016.

QUANDT, Christiane (2015). Efeitos do medial em A guerra dos bastardos (2007) de Ana Paula Maia. Brasiliana - Journal for Brazilian Studies, London, v. 3, n. 2, p. 297-320.

SLOTERDIJK, Peter (2000). Normas para el parque humano. Tradução de Teresa Rocha Barco. Madrid: Siruela.

VALCÁRCEL, Amelia (1994). Sexo y filosofía. Sobre "mujer" y "poder". Barcelona: Anthropos.

ŽIŽEK, Slavoj (2013). Sobre la violencia. Seis reflexiones marginales. Tradução de Antonio José Antón Fernández. Barcelona: Espasa Libros; Austral.

ZOLIN, Lúcia Osana (2007). Valsa negra, de Patrícia Melo: gênero e representação. Maringá, Maringá, v. 29, n. 2, p. 107-111.

Recebido em fevereiro de 2016.

Aprovado em julho de 2016.

\section{resumo/abstract/resumen}

\section{Representações da violência em $\boldsymbol{A}$ guerra dos bastardos, de Ana Paula Maia}

Elena Losada Soler

O romance A guerra dos bastardos, de Ana Paula Maia, apresenta um denso painel de violências ficcionais, e o fato da sua autoria feminina é relevante para a nossa análise. Encontramos nesse texto todas as formas referidas no triângulo de Johan Galtung: violências visíveis ou diretas e invisíveis ou estruturais e culturais, assim como diversas manifestações da violência simbólica tal como analisou Pierre Bourdieu. Essas violências são representadas com técnicas diversas: brutalismo, ironia, "gore" distanciamento etc. Este trabalho tem como fulcro a análise dessas formas de representação e, em especial, do tratamento literário dado à descrição da violência contra a mulher e da violência da mulher.

Palavras-chave: violência, representações literárias da violência, escrita de mulher, Ana Paula Maia. 


\section{Representations of violence in A guerra dos bastardos, by Ana Paula Maia}

\section{Elena Losada Soler}

The novel A Guerra dos Bastardos, by Ana Paula Maia, presents a dense tableau of fictional violence. This text contains all forms of violence included in Johan Galtung's triangle: visible or direct violence and invisible or structural and cultural violence, as well as various forms of symbolic violence, as proposed by Pierre Bourdieu. These types of violence are represented through different textual strategies: brutalism, irony, "gore" distancing etc. This essay analyses these forms of representation, paying particular attention to the literary treatment given to the description of both violence against women and violence by women. In addition, of central importance to this analysis is the issue of female authorship.

Keywords: violence, representations of violence in literature, female authorship, Ana Paula Maia.

\section{Representaciones de la violencia en A guerra dos bastardos, de Ana Paula Maia}

\section{Elena Losada Soler}

La novela A Guerra dos Bastardos, de Ana Paula Maia presenta un denso cuadro de violencias ficcionales. El hecho de su autoría femenina es relevante para nuestro análisis. Encontramos en este texto todas las formas de violencia contenidas en el triángulo de Johan Galtung: violencias visibles o directas, invisibles o estructurales, y violencias culturales, así como diversas manifestaciones de la violencia simbólica como la analizó Pierre Bourdieu. Estas violencias son representadas con técnicas diversas: brutalismo, ironía, "gore", distanciamiento etc. Nuestro trabajo tiene como eje el análisis de estas formas de representación, y en especial el tratamiento literario dado a la descripción de la violencia contra la mujer y de la violencia ejercida por la mujer.

Palabras clave: violencia, representaciones literarias de la violencia, autoría de mujer, Ana Paula Maia. 